\title{
Evaluation of Electrical Installation Training Conducted by the Employment Training Center of Pandeglang Regency, Banten, Indonesia
}

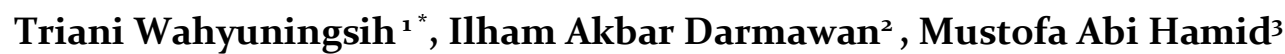 \\ 1,2,3Electrical Engineering Education Department, Universitas Sultan Ageng Tirtayasa \\ Raya Ciwaru Street Number 25, Serang, Indonesia \\ * Author Correspondence.Email: triyani.wahyuningsih12@gmail.com, Telp.+6281319119405 \\ Received: 04 July 2021; Revised: 12 August 2021; Accepted: 25 October 2021
}

\begin{abstract}
This research aimed to explore the results of the evaluation of Electrical Installation Training of the Technical Support Unit of Employment Training Center of Pandeglang Regency based on aspects including context, input, process, product, and outcome, so that recommendation can be obtained for the next training. This study employed a qualitative descriptive method. The CIPPO evaluation model was used in this study. The results indicated that while the setting, process, and product elements could be classified as satisfactory, the input and outcome aspects remained in the poor category. Nonetheless, even with remaining limitations in terms of input and implementation outcomes, the training program can run well. This electrical installation training can be extended by strengthening program components on the input side, particularly facilities and infrastructure, as well as on the output side, in order to maximize labor absorption and reduce unemployment.
\end{abstract}

Keywords: Evaluation, CIPPO Model, Electrical Installation Training

How to Cite: Wahyuningsih, T., Ilham, A.D., \& Mustofa A.H. (2021). Evaluation of Electrical Installation Training Conducted by the Employment Training Center of Pandeglang Regency, Banten, Indonesia. JPPM (Jurnal Pendidikan dan Pemberdayaan Masyarakat), 8(2), 169-185 doi: 10.21831/jppm.v8i2.42116

\section{Introduction}

As stated in Article 27 (2) of the 1945 Indonesian Constitution, the issue of employment and a good standard of living is critical to the nation's survival. Employment remains a long-term issue in a developing country like Indonesia. Economic potential has absorbed a significant number of new workers and continues to grow at a quick pace each year. Given the workforce's critical position as the primary instrument of national development, it is crucial to make measures to enhance the workforce's quality and broaden its contribution to national development.

Meanwhile, the condition of the labor market in Pandeglang Regency decreased in 2019 compared to 2018. The labor force participation in 2019 was 91.29 percent, down from 91.67 percent in 2018. Unemployment is defined as a reduction in the number of unfilled job openings or open unemployment as well as the remaining unemployed workforce, which was a decrease by 0.41 percent compared to that of 2018 (Pandeglang, 2020).

Evaluation, in essence, can provide information that can be used to make decisions. A program is a plan that consists of numerous sections with policies and a set of activities that must be completed over a specific time period (Ananda \& Rafida, 2017). 
JPPM (Jurnal Pendidikan dan Pemberdayaan Masyarakat), 8 (2), 2021 - 170

Triani Wahyuningsih, Ilham Akbar Darmawan, Mustofa Abi Hamid

This evaluation is useful in determining if a program should be continued, altered, or terminated. The evaluation will also assess the success of each program that has been executed (Munthe, 2015). Meanwhile, Darojat and Wahyudiana (2015) state that evaluation is used to determine the level of program success, and that decision is then used to determine whether the program is continued, postponed, enhanced, developed, accepted, or rejected.

A program evaluation is a set of activities carried out deliberately and meticulously to establish the level of implementation or success of a program (Setiyaningrum, 2016). The assessment procedure necessitates the usage of an evaluation model, and the CIPPO model is a modification produced by Gilbert Sax from the evaluation of the Stufflebeam CIPP model program. The CIPPO program evaluation model is made up of five assessment aspects: context, input, process, product, and outcome, all of which are important in evaluating the program as a whole. Meanwhile, the CIPP program evaluation simply looks at the product and does not consider the program's impact. An outcome evaluation (Susilawati et al., 2016) is included in this study, which assesses whether participants who have completed the program are able to secure jobs, namely the competence of training participants from competency-based training programs in the commercial and industrial sector.

Because it contains both a formal and a complete assessment, the CIPP assessment model is a more comprehensive assessment model. Context, input, process, and product evaluation can be performed in the context of decision making (prior condition) and information presentation related to responsibilities (integrated role) (Mahmudi, 2011). The Employment Training Center is a facility where trainees can learn and master a specific type and level of work competence in order to enter major labor markets and/or independent firms, as well as a place for training to raise work productivity in order to improve welfare (Permenaker, 2017).

The Employment Training Center, as a vocational education institution, requires more attention in order for its management to function optimally. Vocational education is built on three pillars: meeting the desires of people who want to work, expanding educational options, and giving high motivation to enhance various forms of learning (Darmawan et al., 2019). The Center is more than just a place to create skilled output; it also makes it simpler to work and be an entrepreneur, thus it is envisaged that the Center's activities will eventually reduce the rate of unemployment (Daud, 2019).

There are various parts in the CIPPO evaluation paradigm, including context, input, process, product, and result. In these areas, components such as the curriculum, facilities and infrastructure, training management, human resources such as teachers and training participants, and other committees are examined. The curriculum is a learning guide that includes materials and training learning strategies. In general, facilities and infrastructure are instruments and equipment that aid in the learning process when performing public services in order to fulfill educational goals. The aims and learning process will not be attained adequately if the facilities and infrastructure are not appropriately provided.

\section{Method}

This research employed a form of evaluation that is program evaluation. In this study, the curriculum for the electrical installation training was evaluated. This was an evaluation study carried out at the Pandeglang Employment Training Center. The 
research subjects for this study were training participants, training instructors, the organizing committee, and the head of the Employment Training Center of Pandeglang Regency. The assessment model employed was CIPPO (Context, Input, Process, Product, Outcome), which is a revision of Stufflebeam's CIPP model. The CIPP model only measures the product or the results of the training, whereas the CIPPO gives an evaluation of the results' implementation, which is to determine how the graduates are performing in the community or in their further education. The research data were collected at the Employment Training Center of Pandeglang Regency. This study was conducted from early June 2021 until July 2021. This study also employed an expost pacto research design for data frim 2020. The chairman, one organizing committee, one electrical installation training instructor, and one electrical installation training participant in 2020 were the sources of data in this research.

The organizers of the training program and participants in the electrical installation training program were the subjects of this study. Respondents in this study included the Pandeglang Regency Training Center's Head, Pandeglang Regency Training Center organizers/managers, electrical installation training instructors, and electrical installation training participants. The objective of this study was to develop an electrical installation training program at the Pandeglang training center that includes context, input, input, process, results, and feedback. This evaluation study used observation, interviews, and documentation studies to acquire data. Data on the existing facilities and infrastructure of the Pandeglang job training center were gathered through observations. Appropriate observation procedures, such as systematic observation and recording of the events being observed, were utilized to examine the availability of supporting facilities and equipment (Redy et al., 2018). (Mania, 2008). Observations were made through monitoring a number of actions during the education and training program's evaluation process (Aryanti et al., 2015). This observation technique yielded narrative information and documentation of input in the form of facilities and infrastructure at the Pandeglang job training center. In addition, interviews were also conducted, which comprised of conversation between two or more persons, with questions typically asked by someone acting as an interviewer with a specific aim (Salim \& Sahrum, 2012). The interview approach employed was a structured interview method with interview guidelines, but it does not rule out the potential of further questions if the informant offered additional information. This interviews were done to gather information about the setting, input, training procedure, training results, and outcomes (reciprocity). The data derived from the interviews were the informants' presentations on the features being evaluated by answering several questions provided by the researchers. Documentation studies were also performed to gather information for this research in the form of supporting materials. These documents were used to learn more about the context aspect, input aspect, aspect, process aspect, and outcome aspect. Documents collected also included a list of names of training participants, instructors' data, a list of organizing committees, a list of participants and instructors attending, training schedules, and others. The documents were then described by the researchers.

Triangulation was used in this research. Triangulation in data collection is a procedure for collecting data and data sources that combines several data collection techniques and existing data sources (Sugiono, 2018). To justify the outcomes of their evaluation work, qualitative evaluators are frequently required to follow a systematic set of processes and means. As a result, they frequently employ triangulation processes 
JPPM (Jurnal Pendidikan dan Pemberdayaan Masyarakat), 8 (2), 2021 - 172

Triani Wahyuningsih, Ilham Akbar Darmawan, Mustofa Abi Hamid

(Amin, 2014). According to the data or information required, data collected were results of observations, interviews, and documentation, which were then analyzed using a qualitative descriptive analysis technique, which consists of three components: data reduction, data display, and drawing conclusions (Sudijono, 2011). The resulting data were then collected and reduced or sorted based on needs. In addition, the reduced data were then presented in a descriptive format. Following the data display, conclusions were taken from each data set obtained. Triangulation was employed to determine the validity of the data in this study, which included source triangulation, time triangulation, and data collecting procedures triangulation. The researchers were able to confirm the validity of the data by employing the triangulation technique. Success criteria were required to determine the outcomes of each evaluation performed. Meanwhile, the success criteria for the evaluation of the electrical installation training program were based on the rules provided by the institution authorized, as the Ministry of Manpower has specific regulations in place addressing the Employment Training Centers and the implementation of Competency-Based Training.

\section{Result and Discussion}

This evaluation research included aspects namely context, input, process, product and outcome.

\section{Context Evaluation}

According to Sax G. (in Widoyoko, 2017), context evaluation is a description and specification of the environment of the program to be implemented as well as unfulfilled demands. The purpose of analyzing the context is to analyze if the training program's objectives have been correctly designed, based on the results of the instructional analysis and taking into account the existence of policies (Prastati, 2011). Context evaluation seeks to assess the whole state of the item by identifying flaws and strengths, diagnosing problems and proposing solutions, and determining whether goals and priorities are appropriate for the needs to be achieved (Tulung, 2014). The findings of the research on the context include: the legal basis employed, the aims, duties, and functions of the employment training center, the relevance of the community's requirements with the training held, and indicators of the program's effectiveness.

\section{Legal Bases for Employment Training}

The legal basis for training in employment training centers is Article 9 No. 13 of the Indonesian Manpower Act of 2003, which outlines job training. The establishment of the Pandeglang Job Training Office Technical Implementation Unit is regulated under Pandeglang Regency Regent Regulation Number 45 of 2018. The vocational training centers were formerly under the authority of the central government, however, the authority has been delegated to the regions, which is regulated in Indonesian Government Regulation number 38 of 2007 concerning the Division of Government Affairs between the Central Government, Provincial Governments, and Regency/City Regional Governments, as well as in Regulation of the Minister of Home Affairs of Indonesia Number 12. As the organizer and organizer of the training program, the Pandeglang Job Training Center refers to Government Regulation No. 31 of 2006 on the Indonesian National Training System.

A successful training implementation program must have a legal foundation or instructions for training implementation in the form of legislation or ministerial rules. 
JPPM (Jurnal Pendidikan dan Pemberdayaan Masyarakat), 8 (2), 2021 - 173

Triani Wahyuningsih, Ilham Akbar Darmawan, Mustofa Abi Hamid

A successful program is one that has been thoroughly prepared and has a solid foundation for implementation. The legal basis for the electrical equipment training program at the Pandeglang's employment training center has been thoroughly evaluated and complies with all requirements for conducting an electrical installation training program, as it already has a sound and clear foundation, namely the program's legal basis.

\section{Duties and Function of the Employment Training Center of Pandeglang Regency}

The Employment Training Center's primary responsibility is to organize job skills training for job seekers, workers, and other community members in need of training and certification. The Employment Training Center's mission is to develop skilled, disciplined, productive, polite, and devout workers for God Almighty, as well as to perform other official duties as assigned. According to the study's findings, this vocational training institution performed admirably in this additional responsibility. However, because there are no specific regulations or affirmations governing the Pandeglang Job Training Center's tasks and functions, this duty is carried out in light of the Employment Training Center's general duties.

\section{Needs Analysis for the Electrical Installation Training}

The purpose of a workplace needs analysis is to ascertain the most critical training requirements (Irianto, 2001). Information on these demands will enable businesses to make the most use of their resources (time, money, etc.) while eliminating superfluous training initiatives. According to the research findings, identifying the training program for need assessment or community needs for electrical installation training at the Pandeglang's Employment Training Center is limited to the package received from the central government, and the Center provides comprehensive electrical installation training. This is purely based on the fact that Banten is densely populated with companies and that residents of Pandeglang can enter the industrial sector through electrical installation training. The electrical installation preparation program's implementation can be viewed as not satisfying the needs of the Pandeglang community. Similarly, the electrical installation preparation program at the Pandeglang Employment Training Center is not being implemented in accordance with the established process for identifying community needs (Ministry of Manpower of the Republic of Indonesia, 2014).

\section{The Objectives of the Electrical Installation Training}

According to the findings of the research, the electrical installation training program at the Pandeglang Employment Training Center has been implemented for the purpose of providing Industrial and Agricultural Training through Competency-Based Training, Community-Based Training, and Mobile Job Training. The Center's Electrical Installation Training Program has a well-defined training aim, adheres to a high standard of implementation, and is generally satisfactory. A good and clear goal will generate a favorable view from the community and will be regarded positively by the community. The Pandeglang employment training center has accomplished its objective well. 
JPPM (Jurnal Pendidikan dan Pemberdayaan Masyarakat), 8 (2), 2021 - 174

Triani Wahyuningsih, Ilham Akbar Darmawan, Mustofa Abi Hamid

\section{Success Indicators for the Electrical Installation Training Program}

A program is continually seeking success, and in order to determine if the program has been effective or not, an indicator of program success is created. According to the research findings, the electrical installation training program at the Employment Training Center of Pandeglang has indicators of program success, namely successful completion of programs by participants, demonstration of high levels of competence, and preparedness to compete in the labor market. According to the data on the training program's success indicators, the electrical installation training program's execution at the Center can be judged to have had extremely clear and positive signs of program success. Thus, the presence of these indicators can serve as a barometer for the program's effectiveness at the Employment Training Center of Pandeglang.

\section{Input Evaluation}

Input evaluation provides data that can be utilized to evaluate the most effective use of resources to accomplish program objectives. Additionally, input can be referred to as preparation prior to the start of a training program (Eriza Nugrahvianti Fadilah, 2014). Meanwhile, the input evaluation components include the following: a) Human Resources, b) Facilities and infrastructure, as well as supporting equipment, c) Funds/budget, and d) Various procedures and rules that may be required. Additionally, the input evaluation examines the readiness of training participants, instructors, organizers, materials, and training facilities and infrastructure (Adhim \& Wiyono, 2015). This input can be evaluated on a variety of levels, including human resource readiness (organization committee, participants, instructors), budget, and existing facilities and infrastructure.

\section{Human Resources}

Human resources is a critical factor in determining the success of a program. These human resources include the organizing committee's readiness, the instructor's readiness, and the training participants' readiness. The organizers of the electrical installation training at the Pandeglang Regency Job Training Center are divided into two committees: the committee responsible for recruiting training participants and the committee responsible for organizing the training program. The following is a list of the members of the organizing committee for the electrical installation training program.

Table 1. The list of the members of recruitment committee of the Employment Training Center of

\begin{tabular}{|c|c|c|c|}
\hline \multicolumn{4}{|c|}{ Pandeglang Regency } \\
\hline No & Name & $\begin{array}{l}\text { Education } \\
\text { Background }\end{array}$ & Positions \\
\hline 1. & Joko Sotejo, S.Pd & $\begin{array}{l}\text { Bachelor of } \\
\text { Education }\end{array}$ & Instructor \\
\hline 2. & $\begin{array}{l}\text { Yuniarti } \\
\text { Wulandari A.Md }\end{array}$ & $\begin{array}{l}\text { Associate } \\
\text { Degree }\end{array}$ & Instructor \\
\hline 3. & Herry Islachudin & $\begin{array}{l}\text { High School } \\
\text { Diploma }\end{array}$ & $\begin{array}{l}\text { Support } \\
\text { Officer }\end{array}$ \\
\hline 4. & $\begin{array}{l}\text { Riska Dwi Cahya, } \\
\text { SE }\end{array}$ & $\begin{array}{l}\text { Bachelor } \\
\text { Degree }\end{array}$ & Instructor \\
\hline
\end{tabular}


JPPM (Jurnal Pendidikan dan Pemberdayaan Masyarakat), 8 (2), 2021 - 175

Triani Wahyuningsih, Ilham Akbar Darmawan, Mustofa Abi Hamid

Table 2. The List of Organizing Committee Members of Employment Training Center of Pandeglang Regency

\begin{tabular}{llll}
\hline No. & Name & $\begin{array}{l}\text { Education } \\
\text { Background }\end{array}$ & Position \\
\hline 1. & Mulyana, S.Pd. & Bachelor Degree & Instructor \\
\hline 2. & Sutrisno & $\begin{array}{l}\text { High School } \\
\text { Diploma }\end{array}$ & $\begin{array}{l}\text { Admin and Support } \\
\text { Officer (Inventory, } \\
\text { Storage, Library } \\
\text { Administration) }\end{array}$ \\
\hline 3. & Rizki Faturrahman, S & Bachelor Degree & $\begin{array}{l}\text { Administrator for } \\
\text { Human Resources } \\
\text { and Internal Affairs }\end{array}$ \\
\hline $4 \cdot$ & Jokri, ST & Bachelor Degree & Instructor \\
\hline
\end{tabular}

While the implementation of this training program has been generally satisfactory, it does have several shortcomings, including the lack of an adequate number of Human Resources at the Pandeglang Regency Employment Training Center to ensure that employees can continue to fulfill their obligations concurrently. This will undoubtedly disturb these workers' centralization of labor. The electrical installation training program's instructors are responsible for delivering education and training in line with the program's curriculum and syllabus. At the Pandeglang Regency Employment Training Center, the electrical installation training program is taught by two instructors. The Ministry of Manpower is responsible for and regulates the recruitment of instructional personnel at the Pandeglang Regency Employment Training Center.

Table 3. The List of the Electrical Installation Training Instructors

\begin{tabular}{llll}
\hline No & Name & $\begin{array}{l}\text { Education } \\
\text { Background }\end{array}$ & Position \\
\hline 1. & Budi Santoso, ST & $\begin{array}{l}\text { Bachelor } \\
\text { Degree }\end{array}$ & Instructor \\
2. & Farida Yuanita W, ST & $\begin{array}{l}\text { Bachelor } \\
\text { Degree }\end{array}$ & Instructor \\
\hline
\end{tabular}

According to the results of observations at the Pandeglang Regency Employment Training Center, the electrical installation instructors have developed an effective program, and the instructors possess adequate abilities as a result of completing the instructor competency test. Additionally, the framework of the electrical installation training program meets the Employment Training Center standards outlined in Ministerial Regulation No. 8 of 2017.

The electrical installation training program at the Pandeglang Regency employment Training Center is open to residents of the Pandeglang area who wish to participate in the training. They had previously registered and received an account from the Ministry of Manpower, and then re-registered at the registration counter, specifically at the administrative section of the Center, after passing the recruitment committee's written test or interview test. Additionally, they have fulfilled the equipment documentation requirements and are considered to have conformed with the provisions. The electrical installation training program has a maximum of 16 
JPPM (Jurnal Pendidikan dan Pemberdayaan Masyarakat), 8 (2), 2021 - 176

Triani Wahyuningsih, Ilham Akbar Darmawan, Mustofa Abi Hamid

participants, and the first batch of electrical installation training program had a maximum of 16 participants who were eligible to join the program.

According to the research findings, the readiness of the training participants was satisfactory, as the trainees who wished to engage in the electrical installation training had already participated in a series of recruitments conducted by the committee. Then, on average, participants were people who genuinely want to work and attend training in order to improve their abilities and access information about job openings more quickly.

\section{Facilities and Infrastructures}

Apart from human resources, the success of a program is determined on the Center's facilities and infrastructure. Infrastructure refers to equipment that is employed indirectly to accomplish educational goals, such as location, school buildings, sports fields, and money. Meanwhile, means refers to tangible equipment used to accomplish educational objectives, such as rooms, books, libraries, and laboratories (Prastyawan, 2016). Infrastructure includes numerous components of the Pandeglang district employment training center (Indonesia, 2017), including learning resources, practice equipment, study and practice room amenities, as well as supporting facilities such as places of worship, restrooms, canteen rooms, and land parking.

The electrical installation training program at the Pandeglang district job training center makes use of learning resources provided to participants in the form of learning modules. This module is designed to supplement the theoretical instruction provided during the electrical installation training program. Additionally, practical tools and functional materials are used as learning resources. Electrical installation training resources The learning resources of the Pandeglang district job training center are adequate and fulfill the participants' needs.

According to the findings of researchers' observations and interviews, the workshop room includes the following amenities: a) there is one workshop room that doubles as a theory room; b) there are twenty trainee chairs (wooden chairs); and c) availability of tables and instructor chairs that is 2 tables and 2 wooden chairs, d) one computer unit, e) three in good condition fans, f) one blackboard, g) one projector, $h$ ) two sound systems, i) trash can and cleaning equipment which were in good condition, j) one water dispenser, k) 16 electric lighting installation boards, 1) 8 trainer panels and electric motors, and m) 4 lighting fundamental trainers.

The electrical workshop is in good condition; it is only the age of the building that makes it appear shabby and insufficient. That is because the participants' seats are still made of wood and the room is relatively small due to the use of the same room for the practice and theory sessions. One could argue that the room's general state is insufficient and requires complete refurbishment to ensure the trainees' comfort. Convenience in engaging in learning activities will also have an effect, and the training program's results may be less than optimal as a result of a lack of concentration. To accomplish this, a contribution from the local government is required to renovate the Pandeglang regency employment training center to improve its facilities and infrastructure.

According to the study's findings, the supporting facilities at the work training facility in Pandeglang Regency were toilets, which were still in short supply due to the presence of only two toilets. Then there are no worship facilities such as prayer rooms, canteens, or designated parking lots, and participants and employees are forced to park 
JPPM (Jurnal Pendidikan dan Pemberdayaan Masyarakat), 8 (2), 2021 - 177

Triani Wahyuningsih, Ilham Akbar Darmawan, Mustofa Abi Hamid

in undesignated locations. The room used for training is still insufficient for a multipurpose facility. The figures above indicate that the Pandeglang regency employment training center's supporting facilities are still severely insufficient. This also violates the norms for work training facility infrastructure set forth in Minister of Manpower Regulation No. 8 of 2017.

\section{Funding for the Training Program}

According to researcher interviews, the training program at the Pandeglang regency employment training center, particularly the electricity installation training, is funded by the State Revenue and Expenditure Budget. The funds are derived from the budget plotted in the Activity Operational Guide regulated by the provincial level employment training agency in Serang, and are channeled through the Manpower and Transmigration Office, which then channels the funds to the Pandeglang employment training center in accordance with the budget plotted in the Activity Operational Guide.

As a result of the explanation above, it can be concluded that this training program is funded exclusively through the State Revenue and Expenditure Budget, and that the budget received by the Pandeglang regency employment training center complies with the standards outlined in the Implementation Budget List and Activity Operational Guide. This budget already covers all training expenses, from participant support facilities to participant consumption, transportation replacement fees, and report writing for the employment training center. The researcher limited their analysis to financial management and did not examine the amounts distributed due to careful consideration for sensitive information.

\section{Process Evaluation}

Process evaluation entails gathering audit data and applying it to program implementation. Essentially, this evaluation employs a process evaluation to determine the effectiveness of the plan's implementation and which components require improvement (Widoyoko, 2017). The training program's implementation process must be carried out as efficiently as possible, as it is from this implementation that the training program's results are decided. Additionally, the training process begins with the recruitment of training participants, followed by the development of a training schedule and the evaluation of attendance, materials, curriculum, learning methods, learning models, and the use of learning media, as well as the learning evaluation process and competency exams.

\section{Recruitment of Trainees}

The recruiting procedure for training participants began well in advance of the start of the course, and for Batch 1 in 2020, recruitment began in January 2020. To spread the word about this electrical installation training, the organizers distributed pamphlets directly and via WhatsApp from the job training center employees in Pandeglang district to family and friends. Additionally, with the growth of social media, information about training implementation has begun to be disseminated via social media, specifically Facebook. 
JPPM (Jurnal Pendidikan dan Pemberdayaan Masyarakat), 8 (2), 2021 - 178

Triani Wahyuningsih, Ilham Akbar Darmawan, Mustofa Abi Hamid

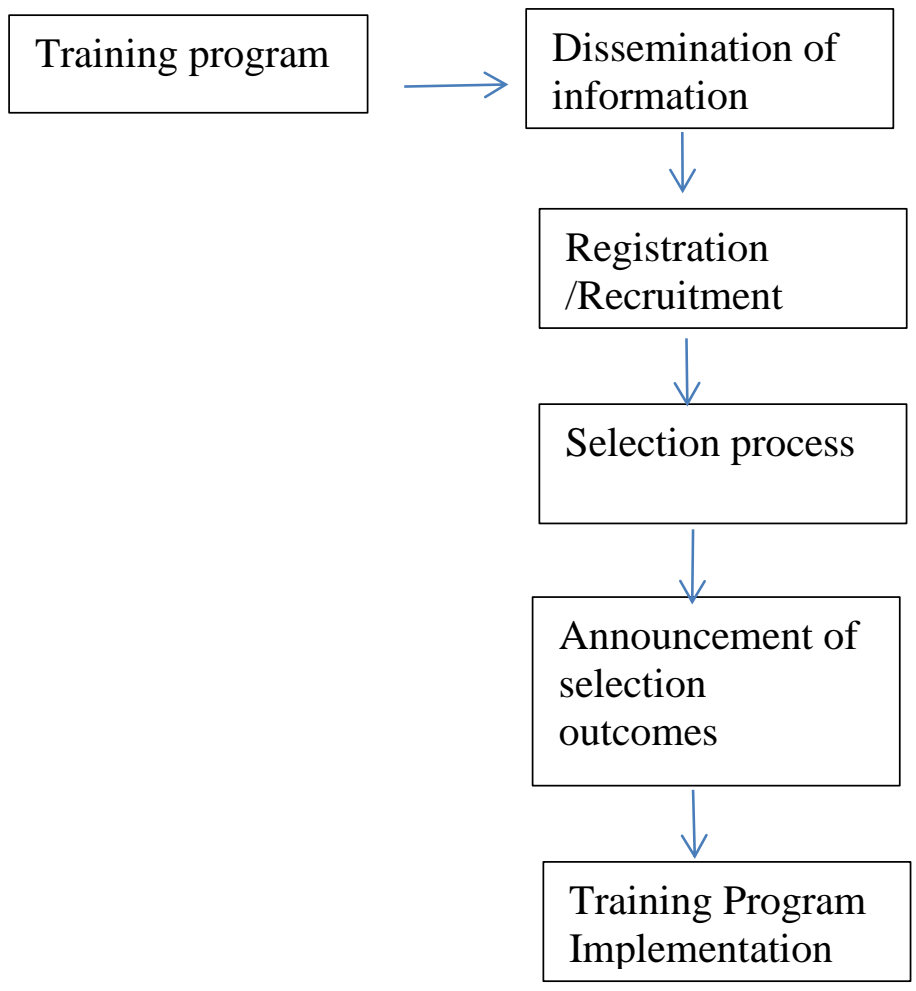

Figure 1. The Flow chart of the Recruitment Process

The registration procedure for becoming a trainee at the Pandeglang regency employment training center include disseminating information and then establishing an account with the Ministry of Manpower. Following that, the recruitment party administered tests; there were two types of tests, a written test and an interview test. When prospective participants have completed the test, they would be informed promptly of the course. It typically takes approximately 1-2 weeks to receive the results. When the prospective trainees are declared to have passed the tests, they will formally become trainees at the Center. According to the flow chart, the recruitment of training participants follows the established scheme in Ministerial Regulation No. 8 of 2014 on recommendations for implementing competency-based training. This program qualifies as having adequate system in order to recruit trainees at the Pandeglang Employment Training Center.

\section{Schedule of the Electrical Installation Training Program}

The electrical installation training was conducted at the Pandeglang Regency Employment Training Center from February 27, 2020 to June 27, 2020, totaling 26o hours of instruction. The calendar of activities for the electrical installation training program is shown in Table 4 below. 
JPPM (Jurnal Pendidikan dan Pemberdayaan Masyarakat), 8 (2), 2021 - 179

Triani Wahyuningsih, Ilham Akbar Darmawan, Mustofa Abi Hamid

Tabel 4. Schedule of the Electrical Installation Training Program

\begin{tabular}{|c|c|c|}
\hline No. & Time & Activity \\
\hline 1. & $\begin{array}{lr}07.45 & -10.45 \\
\text { Western } & \text { Indonesia } \\
\text { Time } & \\
\end{array}$ & Materials Presentation \\
\hline 2. & $\begin{array}{l}\text { 10.45-11.0o Western } \\
\text { Indonesia Time }\end{array}$ & Break \\
\hline 3. & $\begin{array}{l}11.00-12.30 \text { Western } \\
\text { Indonesia Time }\end{array}$ & Materials Presentation \\
\hline 4. & $\begin{array}{l}\text { 12.30 }-\quad 13.00 \\
\text { Western } \\
\text { Time }\end{array}$ & Break \\
\hline 5 . & $\begin{array}{l}13.00 \quad-\quad 14.30 \\
\text { Western } \\
\text { Time }\end{array}$ & Materials Presentation \\
\hline 6. & $\begin{array}{lr}14 \cdot 30 & -14.45 \\
\text { Western } & \text { Indonesia } \\
\text { Time } & \end{array}$ & $\begin{array}{l}\text { Cleaning equipment } \\
\text { and end of sessions }\end{array}$ \\
\hline
\end{tabular}

By examining the schedule table for the installation training program's learning activities, it is possible to determine that the implementation of learning activities is both good and well organized, as well as consistent with the amount of lesson hours. Due to the duration of time spent practicing each day, it can also be considered productive, since it is neither too long nor too short a method of learning to practice each day.

\section{Records of Attendance and Training Activities}

The attendance records can be used to determine the percentage of training participants who attend or the presence of the training teacher. The existence of trainees serves as an indicator of the students' assessment as well as defining the attitude assessment, that is how the trainees are viewed through the discipline lens. Attendance can also be used to gauge the training participants' interest. Additionally, the attendance criteria decides whether or not the person is eligible to take the competency exam. If a participant is frequently missing classes in significant percentages, he or she will be unable to take the Center's competency exam. The training participants complete the attendance list by signing the attendance register.

\section{Learning Materials and Curriculum of the Training Program}

The learning process in this program can be divided into two components: theoretical learning in the theory room and practical learning outside the theory room (Priyanto, 2017). The following competency unit materials are included in this electrical installation training program: a) occupational health and safety; b) the use of electrical measurement tools; c) wiring installation; d) flexible cable and puncture contact installation; d) simple home electrical installation; e) assembling and installing the Split Connector Panel; and f) earthing of electrical appliances. Additionally, there are various non-competence unit materials that are composed of multiple resources. Not only are participants trained about electrical lighting installations, but also about power installations, including electric motors and single phase and three phase panels. This is done by the instructor to help the students improve their skills. 
JPPM (Jurnal Pendidikan dan Pemberdayaan Masyarakat), 8 (2), 2021 - 180

Triani Wahyuningsih, Ilham Akbar Darmawan, Mustofa Abi Hamid

Considering the discussion above, it can be considered that the material in the electrical installation training program is adequate and consistent with the vocational training center's standards, as well as with the curriculum's competences. The Training program curriculum serves as a reference for organizers as well as instructors in terms of aligning educational and training objectives (Ernawati \& Suyantiningsih, 2020). The curriculum serves as a guide for instructional activities designed to meet the anticipated training objectives. Following the interview, it was determined that the curriculum employed in the training program at the Pandeglang Regency Employment Training Center is competency-based and originates with the central labor and migration agency. After discussing the materials and curriculum, it can be concluded that the materials and curriculum at the Pandeglang Regency Employment Training Center are of high quality and adhere to established standards for employment training centers.

\section{Teaching and Learning Method}

The training materials and methods used in this electrical installation training program are lecture-based and question-and-answer-based. The learning process incorporates both theory and practice, with a ratio of 30\% theory to $70 \%$ practice. The instructor's lecture approach was to impart material through the delivery of theory, or by the information and explanation provided by an image or an explanation of theory or practice. The lecture approach was designed to allow trainees to listen to what the instructor was explaining while questions and responses were conducted to encourage active participation in the classroom. With regards to the learning approach described above, the instructor's strategies for implementing the learning process were generally effective and suited the trainees' needs. As a result, the learning approach used in electrical installation training can be classified as satisfactory.

\section{Learning Media in the Electrical Installation Training Program}

Learning media is a critical component in implementing a training program. Learning media is critical to assisting in the delivery of theory during the course of the training program's learning process. Multiple media are used in this training program: media for theory such as modules/media commands for practice, installation boards and trainers, and projectors and computers for explanation and material distribution. The researchers found that the learning material employed in the implementation of the electrical installation training program were utilized effectively and to their full potential.

\section{Learning Evaluation and Competence Exam}

Evaluation of learning is one of the components that contribute to the success of a program that an educational institution develops. Each time a trainee completes one of the current skills training while completing the electrical installation preparation program at the Pandeglang Regency Employment Training Center, the progress is evaluated. The instructor evaluates trainees by assigning activities that they must do individually or in groups as defined by the teacher. Meanwhile, there is a separate assessment for the instructor's evaluation, in which all participants are assigned a score of 90 and must maintain that score throughout the training; if participants do not participate fully in the training, the value is reduced, and this value can be improved by seeking experience. To ensure the workforce's quality standards, a guarantee in the form 
JPPM (Jurnal Pendidikan dan Pemberdayaan Masyarakat), 8 (2), 2021 - 181

Triani Wahyuningsih, Ilham Akbar Darmawan, Mustofa Abi Hamid

of competency certification, which serves as a skill passport to the world of work, is required. The Certification Agency is the board authorized to grant competency certifications (Han Rahmawan, 2012).

In 2020, the Pandeglang Regency Employment Training Center did not conduct competency tests due to the covid-19 pandemic, which prevented trainees from receiving certificates from the National Professional Certification Agency. However, even though the professional certification body did not conduct the competency tests, the instructor conducted the final evaluation independently by conducting an examination of the trainees to determine their competence. Based on the discussion above, it can be concluded that while the overall evaluation of learning and competency exams went well, the assessment may have been conducted by the instructor, resulting in trainees having a high level of motivation to maintain their grades but lacking a standard reference value. It would be preferable to improve so that graduates of this electrical installation training program will always have a high level of quality and are present in large numbers and competitive the workplace.

\section{Evaluation of Product}

Product evaluation is a process that is used to determine the success of a product in accomplishing its objectives (Darojat \& Wahyudiana, 2015). This evaluation is intended to assess the program's success based on the training program's output. There are two elements to consider: the participants' competencies and the follow-up following the training program's implementation (Darmawan et al., 2020). At this stage, assessessment can be conducted to find out whether the outcomes are consistent with the training objectives and have a beneficial impact (Agusven et al., 2018). Product evaluation is used to assist in making subsequent decisions, both on the outcomes obtained and the actions taken following the conclusion of the program (Tayibnapis, 2019). The training program's output can be measured in terms of the quality of the trainees it produces, as well as the number and percentage of graduates, as well as the trainees' readiness to enter the business or industrial world, in order to determine the program's success.

\section{Quality of Graduate Competencies of the Electrical Installation Training Program}

The quality of the electrical installation training program's outcomes is contingent upon the training participants themselves, namely their level of enthusiasm and original intention to enroll in the program. Attitude changes are also dependent on the participants, as the training instructors at the Pandeglang Regency Employment Training Center can only provide theoretical or practical instruction and mold the trainees' mental and self-confidence. The participants themselves also contribute to their results. The component of attaining the objectives is measured by three indicators: the participants' ability to comprehend the training, their motivation to participate in subsequent training, and their ability to practice skills (Irwan, 2017). However, the majority of participants in the program demonstrated a high level of competency. Meanwhile, interviews with training participants indicate that participants gained a better understanding of electricity and how to install it effectively, appropriately, according to the regulations, and efficiently. 
JPPM (Jurnal Pendidikan dan Pemberdayaan Masyarakat), 8 (2), 2021 - 182

Triani Wahyuningsih, Ilham Akbar Darmawan, Mustofa Abi Hamid

\section{The Number of Trainees and Percentage of Completion of Electrical Installation Training Program among Trainees}

There was one training participant that was enrolled in the electrical installation training program in batch 1 of 2020. The trainee participated in the training program from beginning to end and passed the program, hence the graduation rate was 100 percent. This percentage of graduates was obtained from the Pandeglang regency employement training center alone; there was no graduation based on the Professional Certification Institute's competency test. This was because the 2020 training participants did not sit for the institution's competency certification tests. The graduation rate of electrical installation training participants at the Pandeglang employment training center indicates that participant participated in all aspects of the electrical installation training program, or met the program's achievement indicators accordingly.

\section{Trainees' Readiness in Entering Labor Market in the Industry and Entrepreneurship}

Electrical installation trainees already have a willingness to work. It can serve as a motivator for trainees to be prepared to enter the world of employment. The knowledge and abilities acquired through the Pandeglang Regency Employment Training Center's electrical installation training program can prepare trainees to compete in the world of work. Additionally, the training materials include information on lighting installation and extra knowledge on electric motors and panels, as these topics are also required.

After completing the program, it can be determined that the participants are prepared to enter the job market in the industry. The trainees are already prepared due to their intrinsic motivation to work. Additionally, the knowledge and abilities acquired throughout training strengthen the learners' readiness to compete in the industrial or corporate environment. However, the trainees from Pandeglang lacked the mental resilience necessary to labor outside of town for extended periods of time. This is because trainees who work in areas outside of the city are generally uneasy, resulting in their employment being brief.

\section{Evaluation of Outcomes}

Numerous factors can be considered while evaluating the outcome, including the reciprocity between training participants and the vocational training center, as well as the reciprocity between the vocational training center and industry. The purpose of this evaluation was to measure the level of employment in the industry as a result of training at the Pandeglang Regency Employment Training Center.

\section{Outcomes Monitoring in regards to Information Exchange Reciprocity between Trainees and the Pandeglang Regency Employment Training Center}

After trainees complete the program, the Pandeglang Regency Employment Training Center continues to serve the trainees by guiding individuals who desire employment. As a result, the Center assists people in locating employment opportunities in the industry, namely through collaboration with many industries in multiple geographies. However, the Pandeglang Regency Employment Training Center has not engaged extensively with the electricity industry. When training participants graduate, the Center will give information about job openings to them via private Whatsapp messaging for 1-2 months following their training completion. Meanwhile, 
JPPM (Jurnal Pendidikan dan Pemberdayaan Masyarakat), 8 (2), 2021 - 183

Triani Wahyuningsih, Ilham Akbar Darmawan, Mustofa Abi Hamid

the reciprocity between training participants and the Pandeglang Regency Employment Training Center is evident in the performance of participants who are already employed or self-employed. This, however, has not been recorded by the Pandeglang Regency Employment Training Center because the majority of trainees did not report their employment status to the Center. In that situation, the Center shares information on job openings to individuals using Whatsapp messaging, albeit not optimally. Trainees are requested to supply information about their current employment and the length of time they have been self-employed. However, many training participants continue to withhold information on this topic, preventing the training center from monitoring its graduates and the number of unemployed ones. According to the discussion above, there is a lack of reciprocity between training participants and the Pandeglang Regency Employment Training Center. Numerous improvements are required to the monitoring of graduates of the electrical installation training program.

\section{Evaluation of Outcomes in regards to the Pandeglang Regency Employment Training Center and Industry}

The degree of reciprocity in terms of employment information and evaluation from industries that have partnered with job training centers can be determined by the job prospects and work attitudes of graduates who work in those industries. Due to the lack of an industrial sector suitable for training in Pandeglang, trainees seeking employment are willing to work outside the town. However, individuals who had previously worked there typically worked for a little while due to the lengthy commute and the individual's discomfort in the new workplace. This results in a negative appraisal of those who work as graduates of the Pandeglang Regency Employment Training center. Additionally, there is scarce collaboration initiatives between the Center and industry. Meanwhile, the discussion above indicates that the evaluation of ourcomes reflects the low degree of reciprocity between the Pandeglang Regency Employment Training Center and industry, and the reciprocity between training participants and the Center in regards to employment information report needs improvements.

\section{Conclusion}

The following are the conclusions gained from this research. In this evaluation, the context of the electrical installation training program is considered as appropriate and in compliance with work training center standards. The evaluation of the electrical installation training program's input components shows that inputs are inadequate. The evaluation of the process (implementation) of the electrical installation training program is satisfactory, and the process of implementing the training program has been proceeding according to the criteria for organizing training centers. The evaluation of the product aspects of the electrical installation training program is satisfactory; the percentage of training participants who pass is $100 \%$, and the training program has satisfied all of the program's performance indicators. An evaluation of the electrical installation training program's reciprocity reveals a lack of reciprocity between participants and employment training centers.

\section{References}

Adhim, T. Al, \& Wiyono, G. (2015). Evaluasi Program Pelatihan Instalasi Penerangan di Balai Latihan Kerja Kabupaten Pati. E-Journal Universitas Negeri Yogyakarta, 5(2), 79-88. 
JPPM (Jurnal Pendidikan dan Pemberdayaan Masyarakat), 8 (2), 2021 - 184

Triani Wahyuningsih, Ilham Akbar Darmawan, Mustofa Abi Hamid

http://journal.student.uny.ac.id/

Agusven, T., Kusumah, S., \& Haryani, D. S. (2018). Analisis Evaluasi Program Pelatihan Pada Karyawan PT . Sumber Izumi Mas Perkasa Dengan Menggunakan Model IPO. The 7th University Research Colloquium 2018, 5, 182-19o.

Amin, S. (2014). Memperkenalkan Evaluasi Program Secara Kualitatif . Etnohistori, 1(1), 22-32. http://file///C:/Users/User/Downloads/Documents/804-2085-1-SM.pdf

Ananda, R., \& Rafida, T. (2017). Pengantar evaluasi program pendidikan. In Perdana Publishing (Vol. 53, Issue 9).

Aryanti, T., Supriyono, \& Ishaq, M. (2015). Evaluasi Program Pendidikan dan Pelatihan. Jurnal Pendidikan Nonformal, 10(5), 1-13.

Darmawan, I. A., Budiyanta, N. E., Aribowo, D., Fatkhurokhman, M., Hamid, M. A., Guntara, Y., \& Nurhaji, S. (2020). Electricity course on vocational training centers: A contribution to unemployment management. Journal of Physics: Conference Series, 1456(1), o-6. https://doi.org/10.1088/1742-6596/1456/1/012048

Darmawan, Ilham Akbar, Aribowo, D., Desmira, D., \& Ekawati, R. (2019). Efektifitas Kepemimpinan Vokasi Untuk Produktivitas Pembangunan Sumber Daya Manusia Di Balai Latihan Kerja. Jurnal Ilmiah Pendidikan Teknik Dan Kejuruan, 12(2), 107. https://doi.org/10.20961/jiptek.v12i2.32746

Darojat, \& Wahyudiana, M. (2015). model evaluasi , measurement, assessment, evaluation. ISLAMADINA, XIV(1), 1-28.

Daud, D. R. (2019). Program Pelatihan Kerja dalam Meningkatkan Kompetensi Pencari Kerja : Studi Evaluatif Kirkpatrick's Evaluation Model Pada Balai Latihan Kerja Limboto Dinas Tenaga Kerja dan Transmigrasi Kabupaten Gorontalo. Jurnal Pendidikan Islam, 2(1), 143159.

Eriza Nugrahvianti Fadilah, W. R. (2014). Evaluasi Pelatihan Institusional Pada Sub Kejuruan Listrik Industri Di Unit Pelaksana Teknis ( Upt ) Pelatihan Kerja Mojokerto. Jurnal Administrasi Negara, 1-27.

Ernawati, Y., \& Suyantiningsih. (2020). Studi Evaluasi Program Pendidikan dan Pelatihan Komputer di Balai Latihan Kerja Kabupaten Bantul. Jurnal EPISTEMA, 1, 55.

Hanrahmawan, F. (2012). Revitalisasi Manajemen Pelatihan Tenaga Kerja (Studi Kasus Pada Balai Latihan Kerja Industri Makassar). Jurnal Ilmiah Ilmu Administrasi Publik, 1(1), 78. https://doi.org/10.26858/jiap.vii1.135

indonesia, P. mentri ketenagakerjaan nomor 8 tahun 2017. (2017). Standar BLK.

Irianto, J. (2001). Prinsip-prinsip dasar manajemen pelatihan. Surabaya: Insan Cendekia, 1-46. http://file.upi.edu/Direktori/FIP/JUR._PEND._LUAR_BIASA/195603221982031-

DEDY_KURNIADI/ULASAN/Pelatihan_Kajian_Mandiri.pdf

Irwan, M. (2017). Evaluasi program pelatihan keterampilan mengolah limbah kertas semen pada PKBM Cahaya Kota Binjai. JPPM (Jurnal Pendidikan Dan Pemberdayaan Masyarakat), 4(2), 121-132. https://doi.org/10.21831/jppm.v4i2.14100

Mahmudi, I. (2011). CIPP: Suatu Model Evaluasi Program Pendidikan. Jurnal At-Ta'dib, 6(1), 118.

Mania, S. (2008). Observasi Sebagai Alat Evaluasi Dalam Dunia Pendidikan Dan Pengajaran. Lentera Pendidikan: Jurnal Ilmu Tarbiyah Dan Keguruan, 11(2), 220-233. https://doi.org/10.24252/lp.2008v11n2a7

Menteri Ketenagakerjaan Republik Indonesia. (2014). Permenaker 8-2014 Pedoman Pelatihan Berbasis Kompetensi.

Munthe, A. P. (2015). Pentingnya Evaluasi Program di Institusi Pendidikan: Sebuah Pengantar, Pengertian, Tujuan dan Manfaat. Scholaria: Jurnal Pendidikan Dan Kebudayaan, 5(2), 1. https://doi.org/10.24246/j.scholaria.2015.v5.i2.p1-14

Pandeglang., B. K. 2020. (2020). kabupaten Pandeglang Dalam Angka 2020.

Prastati, T. (2011). Program Pelatihan Tutor Universitas Terbuka. Jurnal Evaluasi Pendidikan, 2(2), 206-217.

Copyright @ 2021, JPPM, ISSN 2355-1615 (print), ISSN 2477-2992 (online) 
JPPM (Jurnal Pendidikan dan Pemberdayaan Masyarakat), 8 (2), 2021 - 185

Triani Wahyuningsih, Ilham Akbar Darmawan, Mustofa Abi Hamid

Prastyawan. (2016). Manajemen Sarana dan Prasarana Pendidikan. AL HIKMAH Jurnal Studi Keislaman, 6(1), 35.

Priyanto, S. (2017). Evaluasi Program Pelatihan: Studi Kasus Bagian Mesin Logam di BLK Sleman Tahun 2017. Jurnal Taman Vokasi, 5(2), 230-245.

Redy, P., Jaya, P., Pd, M., Ndeot, F., Pd, M., \& Hi, P. (2018). Peberapan Model Evaluasi CIPP Dalam Mengevaluasi Program Layanan PAUD Holistik Integratif. PERNIK Jurnal PAUD, $1(1), 10-25$.

Salim \& Sahrum. (2012). Metodologi Penelitian Kualitatif.pdf(pp. 1-397).

Setiyaningrum, A. (2016). Implementasi Model Evaluasi CIPP Pada Pelaksanaan Program Pendidikan dan Pelatihan di BPTT Darman Prasetyo Yogyakarta. E-Jurnal Prodi Teknologi Pendidikan, $v(7)$, 265-279.

Sudijono, A. (2011). Pengantar Evaluasi Pendidikan. Rajawali Pers.

Sugiono. (2018). Metode Penelitian Evaluasi (Pendekatan Kualitatof, Kuantitatif, dan Kombinasi). Alfabeta.

Susilawati, Zulfiati, \& Dudung, A. (2016). Evaluasi program pelatihan berbasis kompetensi di unit pelaksana teknis daerah balai latihan kerja karawang (penerapan model evaluasi cippo). 2 , 38-45.

Tayibnapis, F. Y. (2019). Evaluasi Program dan Instrumen Evaluasi untuk Program Pendidikan dan penelitian. Rineka Cipta.

Tulung, J. M. (2014). š $] \mu E v_{-} . I I I(3), 1-16$.

Widoyoko, E. P. (2017). Evaluasi Program Pelatihan. Pustaka Pelajar. 